\title{
Partial blocking and the frustration effect
}

\author{
JOHN L. ALLEN, NANCY L. CAVEN, and LI-AN C. LEONARD \\ Point Loma College, San Diego, California 92106 \\ and \\ M. RAY DENNY \\ Michigan State University, East Lansing, Michigan 48823
}

\begin{abstract}
Nine Sprague-Dawley female rats were trained for 10 days in a straight alley with no obstruction of approach to the goal (four 45-mg pellets). During testing the rats received two nonblocked (0-sec delay) and four partially blocked trials (4-, 8-, 12-, and 20-sec delay with a clear Plexiglas door) per day for 12 days. The 4-sec delay produced significantly faster running than the 8-sec delay; however, contrary to previous research using an opaque blocking door, no significant frustration effect for running or ingestion was obtained. A competing response interpretation is offered as a possible explanation for this discrepancy.
\end{abstract}

The frustration effect as originally reported by Amsel and Roussel (1952) was demonstrated with rats in a double-alley apparatus consisting of a startbox, Alley 1 , first goalbox, Alley 2, and second goalbox. The frustration effect consisted of faster running in Alley 2 when the rat was not reinforced in the first goalbox. Scull (1973) has summarized the results of much of the research involving frustrative nonreinforcement.

The first study specifically designed to investigate the effects of varied intervals of delay in a delay box on Alley 2 running speeds of rats that were never reinforced in the delay box was conducted by Holder, Marx, Holder, and Collier (1957). They observed that following training with a 1-sec delay both the 15-sec and the $45-\mathrm{sec}$ delay groups ran faster in Alley 2 than the 1-sec delay group. Several investigators, on the other hand, have failed to find a frustration effect with a delay procedure (Ludvigson, 1968; Williams \& Ellis, 1970; Wist, 1962). Uyeno (1965) found a frustration effect when each rat was trained with a 0 -sec delay and tested with both 0 -sec and 1 -sec delays; however, he did not find a frustration effect when using a between-groups design.

Allen (1976a, 1976b) used a within-subjects design to investigate the effects of various delay intervals and incentive levels on running speeds and ingestion rates. His studies used an opaque Alley 2 blocking door and reliably produced a frustration effect.

The present study is similar, in most respects, to Experiment 3 of Allen's (1976a) study, with the exception that a clear Plexiglas rather than an opaque Alley 2 door was used. This manipulation will be referred to as

This research was supported by a grant from the Point Loma College Research and Special Projects Fund. The authors wish to express their appreciation to Garth Morse for his technical assistance. Send reprint requests to John L. Allen, Department of Psychology, Point Loma College, San Diego, California 92106. partial blocking, since it physically blocked the rat from entering Alley 2 but allowed it to see the conditioned reinforcer (white alley).

\section{METHOD}

Subjects

The subjects were nine experimentally naive female SpragueDawley rats obtained from a local supplier. All subjects were approximately 90 days old at the start of the experiment, housed individually, and maintained with Allied Mills mouse breeder blocks on a 23 h food-deprivation schedule.

\section{Apparatus}

Except for the length of the alleys, the apparatus was similar to one used by Wagner (1959). The flat black startbox was $1 \mathrm{ft}$ $(30.48 \mathrm{~cm})$ long, and, like the remainder of the apparatus, it was 3 in. $(7.62 \mathrm{~cm})$ wide and $5.25 \mathrm{in} .(13.34 \mathrm{~cm})$ deep. Separating the startbox from Alley 1 was a guillotine-type door painted black on both sides. All other doors in the apparatus were also guillotine. Alley 1 was $3 \mathrm{ft}(91.44 \mathrm{~cm})$ long, painted flat black, and had a floor covered with a black rubber mat. Separating Alley 1 from the delay box was a retrace door painted black on both sides. The delay box was identical to the startbox, except that a guillotine door that opened into Alley 2 was made of clear Plexiglas. Alley 2 contained two Thornton PHC-102 photoelectric cells; one that started a timer was placed $1 \mathrm{ft}(30.48 \mathrm{~cm})$ from the door leading into Alley 2, and one that stopped the timer was placed $2 \mathrm{ft}(60.96 \mathrm{~cm})$ from the same door. Each photoelectric cell was connected to a logic circuit that in turn operated a Thornton DEC-120 5-decade $(1 / 1,000 \mathrm{sec})$ counter timer. The logic circuit consisted of an AND gate and a flip-flop for each photoelectric cell, and it prevented the same photoelectric cell from both activating and stopping the timer. The entire system, including the light sources, was powered by a Thornton APS-101 amplifier power supply. The openings in the alley were covered with thin sheets of red plastic. Alley 2 was $4 \mathrm{ft}(121.92 \mathrm{~cm})$ long, painted white, and had a floor covered with .25 -in. $(6.35-\mathrm{mm})$ mesh hardware cloth. The door separating Alley 2 from the goalbox was painted white on both sides. The goalbox had the same dimensions as the delay box and was painted white; there was a white plastic foodcup mounted in the center of the end wall at floor level. The alleys were constructed of wood and were covered with clear Plexiglas; the startbox, delay box, and goalbox were covered with hinged sections of Plexiglas. 
The runway, power supply, and timer were placed on a table that was centered against one of the walls of the laboratory. Five gray holding boxes with water available were situated against the opposite wall.

\section{Procedure}

Habituation. Preliminary training lasted 10 days, during which a $23 \mathrm{~h}$ food-deprivation schedule was established. Water was available at all times in the home cage. For 3 days, each rat was handled for a 5-min period before being fed for $1 \mathrm{~h}$ in an individual home cage. For the next 3 days, each rat was placed in a holding box for $15 \mathrm{~min}$ before being fed. For the last 4 days, the rats explored the maze in groups of two for $5 \mathrm{~min}$ each day. During this period, the photocells and timer were operating. After exploration, each rat was fed five $45-\mathrm{mg}$ Noyes pellets from the floor of the holding box and then was returned to its home cage.

Training. Each rat was given six 0 sec delay training trials daily during the 10 days of training and received four pellets in the goalbox following each trial. The order in which the rats were run was randomized before each day of training and testing.

A $0-\mathrm{sec}$ delay trial was initiated with the introduction of the rat into the startbox. All doors from the startbox to the goalbox were left open, allowing the rat to traverse the entire length of the runway unobstructed. The first time on each trial that the rat passed through both photobeams while maintaining its goal orientation, the time was recorded as the running time for that trial. If a rat broke only the first beam and then retraced, the timer was reset. As soon as the rat entered the goalbox, the retrace door was closed and ingestion time was recorded. Ingestion time was measured by starting a stopwatch when the rat took the first pellet into its mouth and stopping it when it had taken the last pellet. Each rat was removed from the goalbox as soon as it had eaten.

Testing. Each of the 12 testing days consisted of six trials, two 0 -sec delay trials and four trials on which each rat was held in the delay box for $4,8,12$, or $20 \mathrm{sec}$. The clear Plexiglas Alley 2 door was closed as the rat began its run down Alley 1 and was not opened following the delay intervals until the rat was oriented toward it. The Alley 1 retrace door was closed as soon as the rat entered the delay box. The order in which the intervals were presented was randomized each day, with the stipulation that the two 0 -sec delay trials could not follow each other. Running times and ingestion times were measured and recorded as in the training trials.

After each daily session, the rats were placed in their home cages for $5 \mathrm{~min}$ and then were fed for $1 \mathrm{~h}$.

\section{RESULTS AND DISCUSSION}

All running times were converted to running speeds (feet/second), and all ingestion times were converted to ingestion rates (pellets/second). Only the data for the last 6 days of testing were analyzed, since some time was needed for subjects to habituate to the presence of the delay box doors.

Running speeds across delay intervals differed significantly $[F(4,32)=3.15, p<.05]$. Differences between intervals obtained by Newman-Keuls analysis revealed that the 4-sec running speeds were significantly faster than those following an 8 -sec delay $(p<.05)$. However, no significant frustration effect was found for running speeds; no delay produced significantly faster running than the 0 -sec delay.

No significant difference in ingestion across delay intervals was obtained $[F(4,32)=1.25, p>.05]$ (see Figure 1).

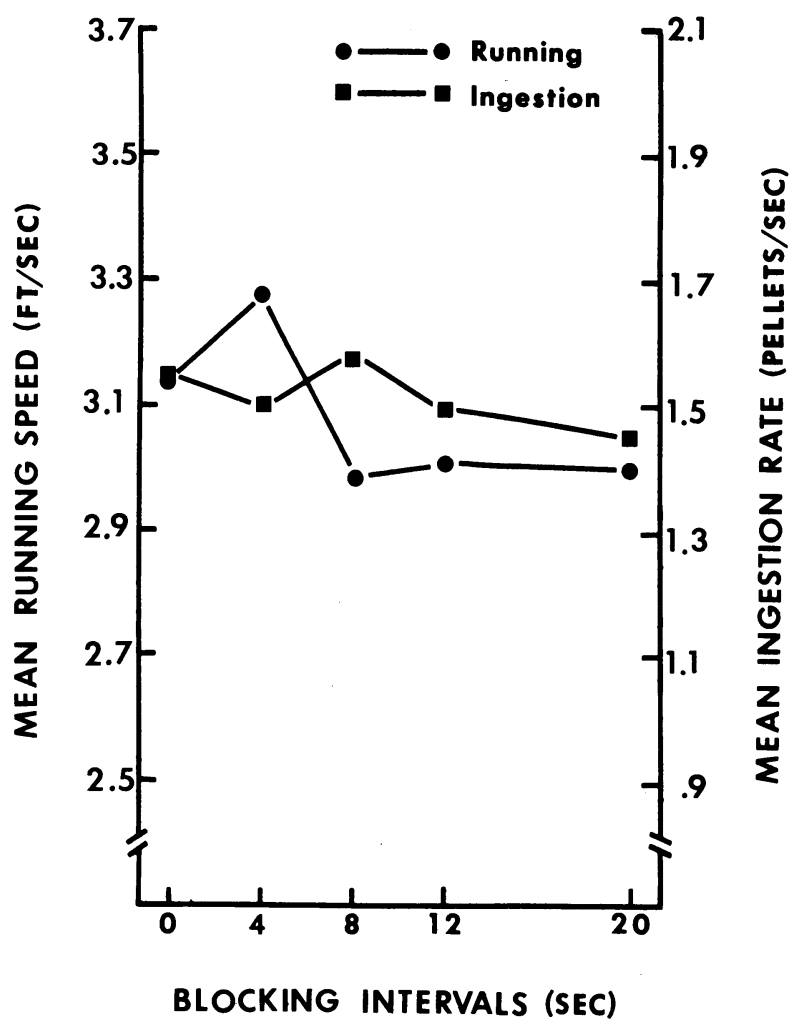

Figure 1. Mean running speeds and ingestion rates at each blocking interval during Days 7-12 of testing.

Contrary to the findings of Allen's (1976a) study that used the same incentive level and blocking intervals, no significant frustration effect for running or ingestion was obtained.

Uyeno (1965) did get a significant frustration effect for running speeds when he used a clear Alley 2 blocking door and a 1-sec delay. One possible explanation for the failure of the present study to obtain a frustration effect is that longer delays allow for more competing responses. Direct observation indicated that during the first 6 days of testing, subjects engaged in considerable biting and scratching at the Alley 2 door and also showed a tendency to turn around. During the last 6 days of testing, biting and scratching decreased while turning and twisting increased. Uyeno's 1-sec delay appears to have been long enough to energize running, but short enough to prevent effective competition. When the delay was $4 \mathrm{sec}$, the mean running speed remained faster, but not significantly faster, than on nondelay trials; moreover, longer delays tended to produce running that was slower than that found on nondelay trials.

The results of the present study are consistent, however, with previous observations (Allen, 1976a, 1976b) that a 4-sec interval tends to produce a faster mean running speed than longer delays. In addition, the results suggest that a blocking door that allows for observation of the conditioned reinforcer tends to elicit competing, 
or withdrawal, responses (Denny, 1971) more than an opaque blocking door, negating any frustration effect. Since no frustration effect occurred in ingestion rate, there is also the possibility that the rats' vigorous alternative behavior dissipated any possible energizing effect of the blocking procedure.

\section{REFERENCES}

Allen, J. L. Frustration effect: The length of blocking interval and magnitude of incentive. Animal Learning \& Behavior, 1976, 4, 61-65. (a)

Allen, J. L. Frustration effect with a long delay. Bulletin of the Psychonomic Society, 1976, 7, 185-186. (b)

Amsel, A., \& Roussel, J. Motivational properties of frustration: I. Effect on a running response of the addition of frustration to the motivational complex. Journal of Experimental Psychology, 1952, 43, 363-368.

DenNy, M. R. A theory of experimental extinction and its relation to a general theory. In H. H. Kendler \& J. T. Spence
(Eds.), Essays in neobehaviorism: A memorial volume to Kenneth W. Spence. New York: Appleton-Century-Crofts, 1971. Holder, W. B., Marx, M. H., Holder, E. E., \& Collier, G. Response strength as a function of delay of reward in a runway. Journal of Experimental Psychology, 1957, 53, 316-323.

Ludvigson, H. W. Interaction of midchain detention and reward magnitude in instrumental conditioning. Journal of Experimental Psychology, 1968, 78, 70-75.

Scull, J. W. The Amsel frustration effect: Interpretation and research. Psychological Bulletin, 1973, 79, 352-361.

Uyeno, E. T. Effect of frustrative blocking on motivation. Psychological Reports, 1965, 16, 203-208.

WAGNER, A. R. The role of reinforcement and nonreinforcement in an "apparent frustration effect." Journal of Experimental Psychology, 1959, 57, 130-136.

Williams, J. L., \& Ellis, J. D. The effects of delay on an established response. Psychological Record, 1970, 20, 251-258.

Wist, E. R. Amount, delay, and position of delay of reinforcement as parameters of runway performance. Journal of Experimental Psychology, 1962, 63, 160-166.

(Received for publication January 26, 1980.) 